\title{
Magistrados y poetas en la España de la Ilustración
}

\author{
Santos M. Coronas González \\ Universidad de Oviedo
}

\section{Resumen}

En la segunda mitad del siglo xvill se dio una singular floración de magistrados poetas desconocida en la historia de la magistratura española. Aunque su aparición pudiera atribuirse a la vocación literaria del siglo, una comprensión más profunda de su obra marcada por un componente político fundamental la vincula más bien a la filosofía de la libertad que caracteriza la Ilustración. J oveIlanos, M eléndez, F orner, Quintana, P osada y Soto, Vaca de Guzmán... representan esa generación de magistrados humanistas que, recordando precedentes clásicos y modernos, lograron superar el antiguo anatema contra la poesía. A excepción de J ovellanos, los restantes magistrados han sido recordados más por su afición a las bellas letras que por su obra profesional. Sin embargo, en la medida que en su propia vida se une la obra poética con la jurídica, parece oportuno armonizar de nuevo en ellos la herencia de Minerva y Themis.

Palabras clave:

Poesía filosófica. Derecho. 
Como tardía floración otoñal, en la segunda mitad del siglo xvIII se dio una singular generación de magistrados poetas desconocida de antes en la historia de la magistratura española. A unque su aparición pudiera atribuirse a la vocación literaria del siglo, una comprensión más profunda de su obra, marcada por un componente político fundamental, la vincula más bien a la filosofía de la libertad que caracteriza la Ilustración. Jovellanos, Meléndez, Forner, Quintana, Posada y Soto, Vaca de Guzmán... representan esa generación de magistrados humanistas que recuerda los antecedentes clásicos de Cicerón y Plinio el J oven 0 , en la tradición española, los precedentes modernos de Crespí de Valdaura y Solórzano Pereira, por más que en el siglo de las Luces se cite con especial predilección el ejemplo de Montesquieu․

Pese a la rápida evolución de las ideas que en el plano cultural y jurídico simbolizan los nombres de Feijoo y Mayans, no resultaba fácil para un magistrado de la época superar el antiguo anatema contra la poesía. Una poesía hinchada y escabrosa, llena de artificio y extravagancia, como la divulgada por Góngora, Vega o Paravicino, ejemplos supremos de mal gusto poético para J oveIlanos y los neoclásicos, no parecía adecuada a la gravedad de la toga. De aquí que la mayor parte de los ilustres magistrados del siglo que al estilo humanista rompieron el círculo del Corpus iuris civilis con su secuela de leges, rationes et auctoritates, no fueran más allá de la historia, de la filosofía moral o de la nueva economía política, sin aventurarse por los campos impropios de la poesía². Para ello hubo que esperar a una promoción de jóvenes magistrados nacidos ya bajo el signo de la reforma que, animados por el ejemplo literario de las hispanas musas renacientes, no tuvieron empacho en continuar las antiguas relaciones del derecho con la poesía. La fuerte impronta jurídica de la épica medieval ${ }^{3}$ y la larga comunicación poética de los legistas universitarios de todas

${ }^{1}$ Carta de J ovellanos a su hermano F rancisco de Paula, dedicándole sus poesías (fines de 1779 o principios de 1780), en G. M. de J ovellanOS, Obras completas. I. Obras literarias, edición crítica, introducción y notas de J. M. Caso González, Centro de Estudios del Siglo XVIII-Ayuntamiento de Gijón, 1984, págs. 5963. R egistra el argumento de autoridad, ciñendo a Cicerón y Plinio el J oven las citas de personajes célebres que J ovellanos ampliara a obispos, sacerdotes, doctores, religiosos y magistrados, A. CEÁn Bermúdez, Memorias para la vida del Excmo. Señor D. Gaspar M el chor de J ovellanos, y noticias analíticas de sus obras. Madrid, En la Imprenta que fue de Fuentenebro, 1814, págs. 313-314. J ovellanos ya por entonces había traducido la deliciosa pieza Cephise et l'Amour que adornaba Le temple de Gnide de Montesquieu $(1725 ; 1743)$ (Obras literarias, págs. 142-145).

2 Campomanes, el ilustre magistrado que sirve de ejemplo a varias generaciones de magistrados y juristas, ha reproducido versos de Horacio y Catulo en su oración gratulatoria con motivo de su admisión en la R eal A cademia de la Historia, y aún, en su círculo íntimo, ha llorado en sentidos versos la muerte de su primogénito, Anselmo, pero no conocemos obra poética al guna que se le pueda atribuir con certeza. Vid. Santos M. Coronas, In memoriam Pedro Rodríguez Campomanes. Oviedo, Real Instituto de Estudios Asturianos, 2002, págs. 156-157; 181-185.

${ }^{3}$ Eduardo DE HINojoSA, «El Derecho en el Poema del Cid» en Obras de D. Eduardo de Hinojosa y Naveros, Madrid, Instituto Nacional de Estudios J urídicos, 1948, págs. 183-215. 
épocas ${ }^{4}$, contribuyeron asimismo a anudar más estrechamente los lazos de la al ta magistratura con una poesía ajena, en principio, a su mundo de valores austeros.

J ovellanos, el joven magistrado que en 1767 accede a la alcaldía de crimen de la Audiencia de Sevilla, fue el primer eslabón de la cadena que unió justicia y poesía. Representante de esa magistratura letrada, independiente y experta que pausadamente se ha ido gestando a lo largo de los siglos bajomedievales y modernos, fue el primero de su siglo en cohonestar la vieja imagen del juez austero e íntegro, de porte juicioso y conducta irreprensible, con una poesía que, por ser todavía mayormente amorosa, parecía «poco digna de un hombre serio»5. De la mano de Cadalso, el «ilustre Dalmiro», ha osado trepar al Parnaso durante su estancia como colegial en el de San IIdefonso de A Icalá de Henares $^{6}$. Después, tras tomar posesión de su plaza en la A udiencia de Sevilla (abril, 1768), mantuvo esta afición, para siempre querida, como un rasgo más de su vivaz personalidad.

En la Sevilla de Olavide, en una ciudad convertida en centro experimental de toda clase de reformas desde las meramente urbanísticas a las sociales, incluyendo el teatro y la universidad, J ovellanos vio alentada su vocación poética en el seno del grupo ilustrado que se reúne en los salones del Alcázar donde tiene su residencia casi principesca el intendente de Andalucía y asistente de la capital ${ }^{7}$. En ella tomó la decisión consciente de repartir sus días entre

${ }^{4}$ Felipe Cortines Murube, «Colegiales poetas en Salamanca. Estudio de un manuscrito literario», en Boletín de la Universidad de Granada, XVI, n.o 75 (1944), págs. 3-110; unas Seguidillas del estudiante, de Diego de Torres Villarroel, recogían esta tradición literaria: «L os más que en Salamanca / son escolares, / sólo estudian de Ovidio / el Arte Amandi, en «Canciones de Estudiantes de Contexto Salmantino», en Miscelánea Alfonso IX. Centro de Historia Universitaria. Universidad de Salamanca, Salamanca, 2000, pág. 268.

${ }^{5}$ Carta de J ovellanos a su hermano F rancisco de Paula, dedicándole sus poesías, pág. 59. Sobre su trayectoria judicial, remito a mi estudio «Jovellanos, jurista ilustrado», en Anuario de Historia del Derecho Español, XLVI (1996), págs. 561-613.

6 Historia de J ovino a Mireo (finales de 1775 o principios de 1776), en J ovellanos, Obras literarias, págs. $76-80$.

$$
\begin{aligned}
& \text { Mezclado a los ilustres } \\
& \text { hijos del gran Cisneros } \\
& \text { allí me vio Dalmiro, } \\
& \text { al margen, por do el viejo } \\
& \text { y sabio Henares fluye } \\
& \text { [... ] Dalmiro, cuyo ingenio, } \\
& \text { ya entonces celebrado } \\
& \text { [... ] De allí (quizá aguijado } \\
& \text { de tan ilustre ejemplo) } \\
& \text { trepar osé al Parnaso. }
\end{aligned}
$$

7 Marcelin Defourneaux, Pablo de Olavide ou I'afrancesado (1725-1803), Paris, Presses Universitaires de France, 1959 (traducción española, M éxico, 1965); F rancisco A guILAR PIÑAL, La Sevilla de Olavide. SeviIla, Ayuntamiento de Sevilla, 1966; Manuel Rıco Lara, J ovellanos en la Sevilla de la Ilustración. Sevilla, 1986. 
Minerva y Themis, dedicando sus ocios profesionales, sus delicta juventutis como los Ilamaría luego, a la poesía y a la literatura, una de las dos secciones en que divide, junto con el derecho, su bien nutrida biblioteca ${ }^{8}$. Que esta afición, incluso en la Sevilla ilustrada, no era comprendida por todos, lo indica el que Ceán, su familiar, amigo y principal biógrafo, se viera obligado a justificarla, y que el propio J ovellanos intentara ocultarla, especialmente en su parte lírica, aconsejando igual recato a su buen amigo R amón de Posada y Soto, oidor de la A udiencia de Guatemala. Escarmentado por la experiencia que le ha hecho conocer el mundo en este punto, pide a su amigo que escriba cuanto quiera, le consulte y franquee sus composiciones a amigos discretos, pero sin publicarlas9.

A hora bien, ¿qué obra poética o literaria había publicado hasta entonces J ovellanos que suscitara tamaña reacción? A la altura de 1778, fecha de esta correspondencia, Jovellanos había redactado la tragedia Pelayo (M unuza) (1769), iniciado la composición de Los españoles en Cholula, tragedia en cinco actos de la que sólo redactó los tres primeros, terminado la comedia EI delincuente honrado (1774), y una menuda poesía amorosa y elegíaca que corría en copias manuscritas. Sin embargo, ninguna de estas obras se había publicado hasta entonces. En 1773, a instancias de sus amigos, había pensado en imprimir la tragedia P elayo que terminara de revisar el año anterior. Para ello redactó un prólogo justificativo, veintidós notas explicativas y una erudita disertación sobre la existencia de Pelayo puesta en duda por Mayans en su Defensa del rey Witiza (Valencia, 1772). Pero, finalmente, desconfiando del mérito de su primera producción dramática, no se resolvió a publicarla por más que, algunos años más tarde, dirigiera su representación por un grupo de aficionados en su Gijón natal ${ }^{10}$. Distinta suerte corrió EI delincuente honrado que, bajo el seudónimo de Toribio Suárez de Langreo, vio la luz en Madrid, en las prensas de la compañía Ibarra, en 1787, después de haber sido impresa de manera desfigurada en Bar-

\footnotetext{
${ }^{8}$ Francisco Aguilar Piñal, La biblioteca de ovellanos (1778), Madrid, Instituto «Miguel de Cervantes», 1984; cf. J ean P. Climent, Las lecturas de J ovellanos, Oviedo, Centro de Estudios del Siglo XVIII, 1980. Casi al final de su vida, cuando recapitula su actividad pública ante uno de los pocos amigos que se mantuvieron firmes en la amistad tras su destierro y prisión, cuando todos al terror doblados medrosos se escondían, podía decir con razón: Sabes que mis días / partidos siempre entre Minerva y Temis / corrieron inocentes, consagrados / sólo al bien público. «E pístola octava. J ovino a Posidonio» (Carlos González de Posada, Valdemosa, 8 de marzo de 1802), en Obras literarias, pág. 300.

${ }^{9}$ Carta de J ovellanos a Ramón de Posada y Soto [¿1778?], en Obras completas. Correspondencia 1.ำ E dición crítica, introducción y notas de J. M. Caso González. Oviedo, Centro de Estudios del Siglo XVIIIAyuntamiento de Gijón, 1985, págs. 142-145. Vid. sobre este magistrado, Vicente Rodríguez García, El fiscal de Real Hacienda en Nueva España (D on Ramón de Posada y Soto, 1781-1793). Universidad de Oviedo, 1986.

${ }^{10}$ Ceán Bermúdez, Memorias, págs. 306-309; Caso, nota previa a la edición de La muerte de Munuza (Pelayo), en Jovellanos, Obras literarias, págs. 353 y ss.
} 
celona por los impresores a ventureros Piferrer y Gibert sin fecha de publicación ${ }^{11}$. Ceán, que ya había justificado con carácter general la afición poética de J oveIlanos en la primera parte de su obra ${ }^{12}$, se vio obligado a justificar en la segunda la composición y el nombre supuesto del autor «temeroso de la preocupación que había entonces, y que tal vez hay todavía en España, contra los magistrados que se dedican a hacer versos, y mucho mas contra los que componen comedias». Recordando el ejemplo de Plinio y la antigua justificación de Cicerón, aducía su propio testimonio de no haber faltado J ovellanos «un punto a las obligaciones de su destino de alcalde de crimen» por la composición del drama; antes bien, de haber trasladado al argumento sus virtudes de a plicación, de pureza y de rectitud, reveladas en máximas tan morales, tan juiciosas y tan análogas a la judicatura ${ }^{13}$. El temor de J ovellanos no nacía, pues, de una experiencia publicista adversa sino de un natural extremadamente sensible, inseguro y crítico que le llevó a desconfiar de la perfección de su propia obra literaria y aun de su adecuación al mundo grave de la toga.

Tragedias, comedias, dramas, idilios, elegías, odas y sonetos hubieron de pasar así por el doble filtro literario y moral de su autor, que, en muchos casos, las condenó al fuego 0 al silencio. A sí lo dice a su hermano Francisco de Paula en la carta dedicatoria de sus poesías de fines de 1779 o principios de 1780 en la que reflexiona sobre «las razones que me obligaron a entregar al fuego la mayor parte de mis versos y a sepultar en el olvido esos pocos» ${ }^{14}$. Estas razones las centraba en la doble injuria que pudieran causar a su profesión la juventud y la pasión que animaran su poesía juvenil, especialmente en su parte lírica («siempre he mirado la parte lírica de ella como poco digna de un hombre serio»). Su profesión de magistrado le imponía una personalidad austera, «un porte juicioso y una conducta irreprensible», capaz de dirigir con la doctrina y de edificar con el ejemplo, pues el público premiaba la aplicación y la virtud de los buenos magistrados con su tributo de estimación y alabanza, "cuyo precio es inmenso», y censuraba sus errores y extravíos con la mayor severidad, casti-

\footnotetext{
${ }^{11}$ J. Sempere y Guarinos, Ensayo de una biblioteca española de los mejores escritores del reinado de Carlos III. Madrid, Imprenta Real, 1785-1789, 6 tomos, (Ed. facs. Madrid, Gredos, 1969), III, pág. 135; CEÁn, M emorias, págs. 312-314; J ohn H. R. PoLt, «J ovellanos "El delincuente honrado"», en The Romanic Review, L (1959), págs. 174-179; J osé M. CASO, «El delincuente honrado, drama sentimental», en La poética deJ ovellanos, Madrid, Ed. Prensa Española, 1972, págs. 193-234; sobre su consideración preeminente como drama judicial vid. Coronas, J ovellanos.

${ }_{12}$ «Sin faltar a las obligaciones de su empleo ni al despacho de estas comisiones se dedicó en Sevilla a la poesía en los días feriados, que eran muchos en aquella época, y en los ratos que le quedaban libres, considerando este ramo de las humanidades como uno de los que deben entrar en el plan de la instrucción pública, y como parte no pequeña de la erudición y literatura española», Memorias, pág. 22.

${ }^{13}$ CeÁn, Memorias, págs. 313-314.

${ }^{14}$ Carta de J ovellanos a su hermano F rancisco de Paula, dedicándole sus poesías, págs. 59-63.
} 
gándol os con el odio y el desprecio. El el evado concepto del honor que tenía J oveIlanos, un concepto a la vez personal, profesional y de estirpe, al preciarse de pertenecer a una de las más antiguas familias de Asturias (cuyo linaje conocido remontaba a la fundación del mayorazgo García J ove a mediados del siglo $x v{ }^{15}$, explica su preocupación constante por el buen nombre que defenderá hasta el fin de sus días como su mayor patrimonio, incluso en las horas amargas del destierro y de la prisión. Este es el trasfondo ideológico de su actitud precavida al que todavía se suma el descrédito de la versificación en un siglo que apenas distingue entre la mala y la buena poesía, dualidad que aboceta diestramente con base en la historia literaria en la carta a su amigo Ramón de Posada.

A unque J ovellanos tenga claro el mérito de la buena poesía, no ocurre lo mismo con la opinión general que bien por ignorancia o por temor ni la premia ni la distingue. "Y aunque no sea yo de esta opinión, debo respetarla, porque cuando las preocupaciones son generales, es perdido cualquiera que no se conforme con ellas.» A sí, en pugna con la preocupación general y, al mismo tiempo, vencido por ella, se presenta a fines de 1775 o principios de 1776 ante los poetas de Salamanca, empeñados como él en honrar la «cuna de las hispanas musas renacientes»: "A strea, que hoy me tiene / en sus cadenas preso, / me trata con ley dura, / y con tirano imperio / pretende ser la sola / señora de mi ingenio» 16. Una ley dura que castiga severamente la liviandad reprensible en un magistrado y que, al cabo, le impondrá su tiránico imperio: «mal de su grado cede / mi corazón al peso / de ley tan inhumana, / y no sin gran tormento a tan severo numen ofrece sus inciensos. / ¡Ay, Dios, los bellos días / pasaron! ¡Pasó el tiempo / de holganza, de venturas / y de contentamientos!»

En su Historia de J ovino a Mireo, donde resume en clave historial vida y obra literaria para sus nuevos amigos salmantinos, les ha dicho que, dejando atrás la poesía clásica, anacreóntica y amorosa, se dedicó a la comedia y a la tragedia sentimental, política y moral de inspiración francesa, que le permitió subir al heroico coturno desde el zueco, reconociendo muchos ricos dones a su influjo: sentimientos («dióme que en largos hilos / de los humanos pechos / mil lágrimas sacara, / mil quejas y lamentos»); amable virtud («por más que / el fraude, el odio negro / y la traición» pintaran «penosos y molestos» sus senderos); lealtad («de lealtad amigo / y a vil perfidia adverso)»; demostración política a príncipes y pueblos... En esta transición poética ha influido igualmente el «forense rumor» del «llanto del opreso, de la viuda y del huérfano» que, a

15 Vínculo mayorazgo de J ovellanos (Gijón, 17, abril, 1548), presentación de J osé M.a Patac de las Traviesas, Gijón, 1977. 85-93.

${ }^{16}$ E pístola primera. Carta de J ovino a sus amigos salmantinos (julio, 1776), en Obras literarias, págs. 
manera de suma bíblica de casos de Corte encomendados a la alta justicia de la A udiencia, ha conmovido su espíritu abriéndolo a un nuevo género literario exhortativo y filosófico moral.

Esta crisis poética de J ovellanos corre pareja con la jurídica, que por entonces, coincidiendo con su ascenso de alcalde de crimen a oidor (1774), le lleva a cuestionar el propio concepto del derecho y la función social de la magistratura. Si la communis opinio, popular y letrada, relegaba el derecho a la simple resolución de las contiendas particulares y «nunca a formar leyes para dirimir las contiendas», no podía extrañar que la inutilidad de su objeto, enredado en mil causas, fatigara la razón que finalmente volvía sus ojos a los principios de la justicia natural, «el único objeto del jurisconsulto» ${ }^{17}$. Estos principios de justicia se encarnaban, mejor que en el antiguo derecho romano, la ratio scripta medieval, en el nuevo derecho natural racionalista, creación del pensamiento jurídico moderno y verdadera piedra de toque de la ilustración jurídica europea. Nacido en las U niversidades alemanas de la segunda mitad del siglo xvII como una creación doctrinal libre, propugnaba la construcción racional de un sistema jurídico basado en los principios del derecho natural, los mismos que al faltar hacían del derecho romano una vana sombra, una imagen sin vida en expresión de H eineccius. I nfluido por la lógica racionalista y la teoría del método, este derecho había venido a emancipar a la ciencia jurídica de un asfixiante romanismo y del dogmatismo de la teología moral. A mpliamente difundido por las universidades centroeuropeas, su mismo espíritu de libre examen racional del derecho y de la sociedad chocaba con la actitud y los principios de la ortodoxia católica, contraria a admitir la separación de la justicia natural de su Creador o de aceptar a la razón como única fuente del conocimiento, ignorando la minusvalía congénita del hombre y su mermada capacidad intelectual y cognoscitiva ofuscada por las tinieblas del pecado original. E sta circunstancia explicaría su tardía recepción en Francia, Italia o España, y aún su misma forzada admisión en estos países, una vez que se impuso la evidencia de su carácter jurídico fundamental superando los ataques romanistas a una disciplina que consideraban no jurídica18.

17 Introducción a un discurso sobre el estudio de la economía civil (Sevilla, 1776), en Obras publicadas e inéditas de D. Gaspar M elchor de J ovellanos, editadas por Cándido Nocedal (BAE, tomos X LVI y L), Madrid, 1858 y 1859; continuadas por Miguel Artola (BAE, tomos LXXXV; LXXXVI; LXXXXVII), Madrid, 1959; vol. LXXXVII, págs. 7-17.

${ }^{18}$ En España esta recepción se produjo con gran prevención oficial depurando el pensamiento de los autores admitidos y orientando su enseñanza, como hacía el Real Decreto de 19 de enero de 1770 que la estableció en los R eales Estudios de Madrid «a demostrar la unión necesaria, de la religión, de la moral y de la política», exactamente lo contrario de los predicado por sus principales representantes Grocio, Puffendorf, Wolf, Thomasius o H eineccius que no en balde estaban en el índice de la Inquisición. De aquí que, fal to de 
Al cal or de este derecho natural y junto al habitual iusprivatismo de la ciencia jurídica, había cobrado nueva vida el olvidado derecho público, sepultado en España en los viejos textos forales y en los diplomas de los archivos polvorientos, así como la economía política, la ciencia que, a juicio de J ovellanos, enseñaba a gobernar. A su luz, los principios de justicia natural deducidos de la razón libre y de la experiencia histórica, debidamente sistematizados por el pensamiento iusracionalista frente al casuismo imperante, fueron ofrecidos por la filosofía del derecho, heredera del derecho natural, a la causa de la Ilustración. Los magistrados ilustrados, adeptos al nuevo orden jurídico racionalista al tiempo que al iushistórico deducido de la propia natural eza del derecho entonces vigente con códigos y leyes de mil años de antigüedad, podían utilizar el cargo para difundir sus principios en obras doctrinales y jurídicas, pero también en obras literarias y poéticas, haciendo válida la antigua máxima de enseñar deleitando. Y este fue el mensaje de J ovellanos a sus amigos de Salamanca en su didáctica de 1776.

Es un magistrado que ha cantado al amor pero también los orígenes libertarios de la historia patria en su P elayo; que ha reflexionado sobre la dureza de la ley penal oponiendo al rigorismo antiguo la clemencia humanitaria de la nueva filosofía; que predica la adecuada proporcional idad de la pena con el delito y que defiende la abolición de la prueba del tormento. Es un magistrado que se ha comprometido con la causa de la libertad, primero económico-política, en la línea preconizada por su mentor y guía Campomanes, fautor de su rápida promoción judicial; luego, histórica, como deduce de sus propios apuntes de derecho público y del estudio de los fueros medievales, depósito genuino de una tradición de libertad no contaminada de romanismo o curialismo; y, finalmente, política, centrada en la vieja constitución esencialmente consuetudinaria de España, la Constitución de los mil años de que hablara el padre Burriel, cuya evolución expondrá en rápido boceto ante la A cademia de la Historia en $1780^{19}$.

clima adecuado, neutralizada la opinión de estos autores por la contraria de los apologistas católicos Desing o Concina o del primer profesor español de esta disciplina Joaquín Marín, este primer ensayo de secularización jurídica, de autonomía relativa del derecho natural de la ética, resultara una experiencia fallida, tanto en Granada como en Valencia. A penas un cuarto de siglo después de su establecimiento fueron suprimidas estas enseñanzas, consideradas esencialmente peligrosas a la luz de las declaraciones independentistas y revolucionarias americanas y francesas, a instancias de inquisidor general Rubín de Ceballos, por Real Orden de 31 de julio de 1794. Sin embargo la luz de la independencia intelectual estaba encendida y la filosofía del derecho, heredera de este derecho natural racionalista, serviría en el futuro, como la propia Ilustración, a la causa de la libertad. Santos M. CORONAS, EI pensamiento jurídico de la llustración en España, en Tomás Montagut (ed.), Història del pensament juridic, Barcelona, Universitat Pompeu i Fabra, 1999, págs. 153-166.

${ }^{19}$ Sobre la evolución del pensamiento político de Jovellanos, vid. Santos M. Coronas, EI pensamiento constitucional de J ovellanos, en Historia Constitucional. Revista electrónica, I (2000): http://constitucion.rediris.es/revista/ he/rhc.html; del mismo autor, "Constitucionalismo histórico y neoforalismo en la historiografía del siglo XVIII», en Notitia Vasconiae. Revista de Derecho Histórico de Vasconia, I (2002), págs. 83-111. 
Esta causa de la libertad, entendida al modo reformista e ilustrado de M acanaz a Campomanes o Moñino, late en la E pístola de J ovellanos a sus amigos de Salamanca de julio de 1776. La suave amonestación para dejar la muelle poesía pastoril, festiva y amorosa en favor de la épica, filosófico-moral y patriótica, que encomienda J ovellanos a M eléndez Valdés, fray Diego González y fray Juan Fernández de Rojas, sin mayor conocimiento de su personalidad respectiva salvo la deducida de su edad y condición, responde al principio moral de servir también desde la poesía a la causa de la libertad ${ }^{20}$. Ella justifica los temas propuestos v.gr. a M eléndez: cantar ilustres hechos históricos que, como las guerras celtibéricas contra el invasor romano, de los cristianos del monte A useva contra los musulmanes o de los comuneros de Castilla contra el nuevo César, Carlos V, hicieran crecer el sentimiento patrio de libertad ${ }^{21}$. Un sentimiento que si por entonces no dio frutos sazonados por lo difícil que resultaba cambiar el rumbo poético juvenil, naturalmente apegado a la dulzura de la poesía anacreóntica, los daría en la segunda generación poética salmantina cuando se radicaliza con los Cienfuegos o los Quintana el valor político de la libertad.

Pese a todo, bajo el influjo de la invención enteramente nueva de que hablara Meléndez en su contestación a Jovellanos, se emprendió el camino del progreso de la poesía en la línea filosófica de la Ilustración. Si ésta, al modo kantiano, se concibe como el uso libre de la razón capaz de liberar al hombre de la tutela de antiguas creencias, en la poesía hubo de dar lugar a un género nuevo, filosófico 0 ilustrado22, al que J ovellanos propende por convicción jurídica no exenta de res-

${ }^{20} \mathrm{~A}$ la vista de este mensaje político-moral, pasa a un segundo plano la antigua acusación a J ovellanos de insensabilidad poética (Real de la R iva) 0 , en el mejor de los casos, de desconocer las condiciones esenciales de la inspiración verdadera (A rce) o la fuerza inevitable de la naturaleza y condición humanas (M enéndez Pelayo). La propuesta de J ovellanos, orientada a la perfección moral del poeta por el objeto de la poesía, orillaba conscientemente la mayor o menor aptitud natural hacia ella así como el estilo a deducir del propio objeto. Esta corriente crítica, planteada con claridad por Leopoldo A. Cueto, Bosquejo histórico-crítico de la poesía casteIlana en el siglo XVIII. Madrid, 1893, (1952) (BAE, LXI), I, págs. CX-CX III, tuvo su continuidad en César REAL DE LA RIVA, "La escuela poética salmantina del siglo XVIII», en Boletín de la Biblioteca Menéndez Pelayo, XXIV (1948), esp. págs. 358-361 y, muy matizada ya, en J oaquín A RCE FERnÁnDEz, «J ovellanos y la sensibilidad prerromántica», ibidem (1960), esp. págs. 152-156. Por contra, CEÁN, Memorias, págs. 22 y 289-292; y Manuel J. Quintana, en su noticia de Meléndez Valdés publicada al frente de las poesías de este autor hecha en la I mprenta Real en 1820 (reproducida en las Obras completas de M. J. Quintana [BAE, XIX, Madrid, 1946], págs. 109121), se mostraron más comprensivos a la hora de apreciar la mejora poética propuesta por Jovellanos.

${ }^{21}$ «Sean tu objeto los héroes españoles / las guerras, las victorias y el sangriento / furor de Marte. Dinos el glorioso / incendio de Sagunto, por la furia / de A níbal atizado, o de Numancia, / terror del Capitolio, las cenizas. / Canta después el brazo omnipotente, / que desde el hondo asiento hasta la cumbre / conmueve el monte A useva y le desploma / sobre la hueste berberisca y suban / por tu verso a la esfera cristalina / los triunfos de Pelayo y su renombre». Epístola primera. Carta de J ovino a sus amigos salmantinos (julio, 1776), en Obras literarias, págs. 85-93. vv. 276-287.

22 Este género poético ilustrado asume los postulados críticos y reformistas de la nueva filosofía hecha a la vez de intemporal cultura clásica y de renovadora ciencia experimental. Su aportación, bien visible para sus contemporáneos en ciertas líneas estilísticas y temáticas (verso suelto, estilo declamatorio, tono sentencioso, 
ponsabilidad profesional. En su epístola didáctica a los amigos salmantinos, pudo presentar este nuevo genero poético como un progreso del espíritu, válido en sí mismo y, por tanto, susceptible de difusión. A ceptado con mejor o peor fortuna poética, el nuevo género filosófico o sublime hubo de abrirse camino con dificultad:

\author{
Excitado de lo que V.S. me dice, he emprendido algunos ensayos de la tra- \\ ducción de la inmortal Iliada - dirá Meléndez a Jovelanos- [... ]. En lo demás \\ no tiene V.S. que esperar de mí nada bueno: los poemas épicos, físicos o morales, \\ piden mucha edad, más estudio y muchísimo genio, y yo nada tengo de esto, ni podré \\ tenerlo jamás ${ }^{23}$.
}

fin moralizante, para A rriaza [prólogo a la edición de sus Poesías de 1807 (BAE, LXVII, pág. 46 b); afectación intolerable de ternura, de filantropía y filosofismo, para Leandro F ernández Moratín (prólogo a sus Obras dramáticas y líricas (1825), encierra el mundo de conceptos y valores propios de la Ilustración: libertad, cultura crítica, científica y humanista y virtud. Si hay un espíritu de las leyes, como ha demostrado M ontesquieu, también puede haber un espíritu poético hecho de filosofía y arte al estilo de Voltaire, Pope o Young. Y en España, aunque al gunos ridiculicen el nuevo género sublime, como Cadalso en «Sobre ser la poesía un estudio frívolo y convenirme aplicarme a otros más serios» (Poetas líricos del siglo XVIII, BAE, LXI, pág. 259), otros muchos se sentirán llamados a emprender el nuevo camino como el «poeta filósofo», Cándido María Trigueros, que se atribuye el mérito de haberlo iniciado con sus Poesías filosóficas (El Poeta filósofo o Poesías Filosóficas, Edición de Francisco A guilar Piñal, Sevilla, 1974). Ni el derecho es ya el antiguo romano ni la poesía la milagrera medieval o la mística y barroca moderna, sino la filosófica moral hecha en ambos casos de razón y de experiencia como ven con facilidad los magistrados poetas. En general, vid. J oaquín A rCE Fernández, La poesía del siglo ilustrado. Madrid, A lambra, 1980, págs. 278-364; Pedro Á lvarez de Miranda, Palabras e ideas: el léxico de la Ilustración temprana en España (1680-1760). Madrid, R eal A cademia Española, 1992; R afael LAPESA, «I deas y palabras: del vocabulario de la Ilustración al de los primeros liberales», en Asclepio (Homenaje a Pedro Laín), XVII-XIX (1966-1967), págs. 189-218; F. A guILAR PIÑAL, «La poesía filosófica de Cándido María Trigueros», en Revista de Literatura, XLIII (1981), págs. 19-36; del mismo autor, Un escritor ilustrado, Cándido María Trigueros. Madrid, Instituto de Filología, 1987; Santos M. Coronas, Ilustración y Derecho. Los fiscales del Consejo de Castilla en el siglo xvill. Madrid, Ministerio para las A dministraciones Públicas, 1992; Elena de Lorenzo Á lvarez, Nuevos mundos poéticos: la poesía filosófica de la Ilustración, Oviedo, Instituto Feijoo de Estudios del Siglo XVIII, 2002.

${ }^{23}$ «De J uan M eléndez Valdés a J ovellanos (Salamanca, 3 de agosto de 1776)», en J ovellanos, Correspondencia, pág. 45. Sin embargo, en la temprana academia cadálsica, Meléndez, al igual que sus condiscípulos legistas A rroyal, Forner y Caseda, había tenido ocasión de reflexionar sobre al gunos problemas cultural es y políticos al calor de la Defensa de la nación española y de la redacción de las Cartas marruecas de Cadalso, inspiradas en el mismo espíritu contrario a las gratuitas acusaciones irónicas de Montesquieu en sus Cartas persas. Como recuerda en sentidos versos Cadal so «¿No más pasar la noche obscura y larga / de enero juntos con preciosos libros / de gustosa moral escrita en verso / por M endoza, León, Lope, Argensola?» Y no sólo de gustosa moral sino también del peligroso derecho público de la mano de Vattel y del Montesquieu del E spíritu de las leyes cuyas obras estudiara (pasara) con Cadalso, sin saber por entonces que estaban prohibidas por la Inquisición ("J uan Meléndez Valdés a J ovellanos», Segovia 11 de julio de 1778, pág. 129). EI decisivo influjo de este período en la formación del pensamiento crítico de Forner, (F. Lopez, J uan Pablo F orner (1756-1797) y la crisis de la conciencia española en el siglo xvIII. Trad. de F. Villaverde. Junta de Castilla y León, Salamanca, 1999, págs. 228 ss), es posible rastrearlo igualmente en A rroyal y Meléndez, que por entonces pone sus propias bases de jurisconsulto poeta en la línea del J anuario (Giuseppe Aurelio di Gennaro) de la República de los jurisconsultos, que, por su ficción natural y seguida, por su puro latín, por sus vivas descripciones, sus elegantes narraciones, su crítica acendrada considerará años más tarde como obra al fin de un jurisconsul to poeta, que entronca con las amenas lecturas de Lorenzo Valla, representante de ese humanismo siempre presente en la alta cultura jurídica europea desde el R enacimiento. 
El reconocimiento de estas carencias no impidió que la primera generación poética salmantina se enfrentara al reto de la poesía filosófica, bien traduciendo 0 imitando model os ya consagrados, caso de Meléndez, que en octubre de 1777 recibe de J ovellanos a manera de estímulo o ejemplo el primer canto traducido del Paradise Lost de Milton, cuya revisión dará por concluida en agosto del año siguiente, bien componiendo poemas nuevos como Las cuatro Edades ${ }^{24}$ de fray Diego González o La noche y la soledad, que pasa por ser «la primera composición filosófica» de Meléndez ${ }^{25}$. En 1777, M eléndez da por rota la cadena que le une al amor y sus errores, pidiendo a las musas voz y fuego para cantar mayores $\operatorname{cosas}^{26}$. A lgunas le vienen inspiradas por la propia vida profesional de J ovellanos, cuya severidad pretende al iviar en sus días con el canto de las Musas lisonjero ${ }^{27}$ y cuyo ascenso a la alcaldía de Casa y Corte (1778) le sugiere la unión de Apolo y Temis en tan alto empleo 0 , como si se tratara de un hermoso lienzo alegórico de Giaquinto, la estrecha unión de la paz y de la justicia («La paz y la justicia / con la equidad sagrada / jamás fueron en lazo tan estrecho / juntas» $)^{28}$. Las quejas posteriores del amigo por el maldito oficio, le llevará a recordar las bondades del trabajo: «más no me negarás cuánta alegría / un corazón resiente virtuoso / por tener así lleno todo el día. / Del mismo trabajar sale gozoso / ... ¡ Oh venturoso el hombre que pudiere / continuo trabajar!, que a su aldabas / ni el vicio tocará ni los placeres» ${ }^{29}$. Pero otros muchos cantos de mayores cosas le vendrán de la lectura de nuevas obras filosóficas, históricas, pedagógicas, jurídicas... (del inimitable Young que inspira su oda La noche y la soledad, de Robertson y Marmontel que le enfrentan con el problema indiano y

\footnotetext{
${ }^{24}$ Leopoldo A. de Cueto, Poetas líricos del siglo XVIII, I, (BAE, LXI), Madrid, 1952, pág. 178.

${ }^{25}$ J uan Meléndez Valdés, Obras en verso. Edición crítica, prólogo y notas por J ohn H. Polt y J orge Demerson, Oviedo, Centro de Estudios del Siglo XVIII, tomo I, 1981; tomo II, 1983; II, págs. 874-883.

26 «Blanda Musa, / dame tu voz y tu divino fuego; / mayores cosas canto, mayor orden / empiezo desde agora; a ti se deba / el levantado verso y voz sonora», "ya del acerbo mal del todo libre, / merced a vos, señor, arrepentido / de haber seguido A mor y sus errores». «E pístola XIII. AI Señor Don Gaspar de J ovellanos, Oidor en Sevilla, sobre mi amor», en Meléndez, Obras en verso, págs. 822 y sS; vv. 194-198; vv. 489491.

${ }^{27}$ «A rrímese la toga, y el severo / ejercicio del foro el paso ceda / al canto de las Musas lisonjero. / Sobrado tiempo a los cuidados queda / ni siempre con su vuelta han de aquejarnos / como queja a I xión la triste rueda», reflexión que va acompañada de una singular advertencia: «y jay del que de las Musas siendo alumno, / ya cual cansado asnillo cede al peso / de un dédalo de leyes importuno!... ;oh dura esclavitud do el albedrío / Ilora cansado y se lamenta preso». E pístola XIV «A J ovino, en sus días» (1777), en Meléndez, Obras en verso, cit. págs. 834-836, vv. 4-9, 46-49, 50-51.

${ }^{28}$ Oda XLVIII «AI Señor Don Gaspar de Jovellanos, Oidor de la R eal Audiencia de Sevilla, y nombrado Alcalde de Corte» (1778), (Obras en verso, págs. 717-720; vv. 78, 92-95).

${ }^{29}$ E pístola XV «Batilo a su amado J ovino» (1778), (0 bras en verso, págs. 837-838, vv. 37-40, 43-45). En los versos anteriores J ovellanos le ha contado sus cuitas («Tener todas las horas ocupadas, / ora en el tribunal, ora en juicio, / y rondar en las noches más heladas; / negarme a la piedad en perjuicio de la santa justicia» (vv. 25-29).
} 
la cuestión moral de la cruel conquista30; de Locke, Condillac y Rousseu con su nueva pedagogía ${ }^{31}$, de M ontesquieu, cuyas Lettres persannes inspiran su proyecto de escribir cada una o dos semanas a J ovellanos las Cartas de un bachiIler sobre diversos puntos en el mismo estilo ligero y breve... ${ }^{32}$ ), responsables asimismo de tempranas disertaciones académicas, como la que le encarga la R eal Sociedad Vascongada sobre el lujo ${ }^{33}$, y de ciertas reflexiones sobre la historia que registrara Sempere en su Biblioteca ${ }^{34}$, por más que, cansado De las ciencias $(1784)^{35}$, añorara en algún momento la antigua forma de vida juvenil y despreocupada, como la reflejada en sus odas anacreónticas. Al final de este período M eléndez declara compartir con J ovellanos un espíritu algo ilustrado y fil osófico ${ }^{36}$ que, dejando atrás amores y ternuras, se orienta hacia la poesía didascálica ${ }^{37}$.

Publicado en 1785 el primer tomo de sus Poesías, ya tenía preparado por entonces un segundo tomo de carácter más grave que por diversas razones no

30 «Yo esta clase de libros (History of the reign of the Emperor Charles V de William R obertson, que probablemente leyera en su versión francesa de A msterdam-Paris, 1771; Les Incas, ou la destruction de I'empire du Perou de Jean François Marmontel, Paris, 1777) los leo con el mayor gusto, porque nada me embelesa tanto como las máximas de buena moral.» Carta de Meléndez Valdés a J ovellanos, Salamanca, 27 de abril de 1779, en Jovellanos, Correspondencia, I, págs. 155-156.

31 Etienne Bonnot de Condillac, Cours d'etudes pour l'instruction du prince de Parme. Parma, 1775, 16 vols; le gustan mucho a Meléndez sus dos primeros tomos (Salamanca, 16 de julio de 1780; Correspondencia, I, pág. 190); un año antes ha leído de J ohn L OCKE, Some Thoughts Concerning E ducation (1693), probablemente en su versión francesa; y de Rousseau, E mile ou de l'education (1762) (Correspondencia, I, pág. 156).

32 «Mi modelo sería Montesquieu», carta de Meléndez a J ovellanos, Salamanca 16 de julio de 1780, en J ovellanos, Correspondencia, I, págs. 185-186. Sobre la posible relación de estas cartas con las Cartas de I brahin que Meléndez pretendió editar sin éxito en 1789, vid. George DemERson, Don J uan Meléndez Valdés y su tiempo (1754-1817), Madrid, Taurus, 1971, 2 vols., I, págs. 162-166.

33 Demerson, J uan Meléndez Valdés, I, págs. 159-161.

34 J. Sempere y Guarinos, Ensayo de un biblioteca española de los mejores escritores del reinado de CarIos III, tomo IV, Madrid, 1787, págs. 63-64.

35 «A pliquéme a las ciencias, / creyendo en sus verdades / hallar fácil alivio/para todos mis males. / ¡Oh! ¡qué engaño tan necio! / ¡Oh! ¡cuán caro me sale! / A mis versos me torno / y a mis juegos y bailes. / [... ] pues los sabios, Dorila, / ser felices no saben. / [... ] Los que estudian padecen / mil molestias y achaques, / desvelados y tristes, / silenciosos y graves. / ¿Y qué sacan? Mil dudas; / y de éstas luego nacen / otros nuevos desvelos, / que otras dudas les traen. / A sí pasan la vida / - jvida cierto envidiable!- / en disputas y en odios, sin jamás concertarse. / Dame vino, zagala», Oda XXVII, Obras en verso, págs. 104105, vv. 1-9, 15-16, 37-49.

${ }^{36}$ Carta de Meléndez a J ovellanos, Segovia, 8 de junio de 1777, en Jovellanos, Correspondencia, I, pág. 61-62.

${ }^{37}$ Carta de Meléndez a J ovellanos, Salamanca, 14 de septiembre de 1776, pág. 50, en la que se declara convertido con sus amonestaciones de escribir amores y ternuras. J ovellanos, en la primera de sus Cartas del viaje a Asturias (edición de Álvaro Ruiz de la Peña y Elena de Lorenzo Álvarez, Oviedo, KRK, 2003), confirma en 1782 esta conversión del amigo a la poesía didascálica porque «cansado del género erótico... ha creído que envilecería las musas si las tuviese por más tiempo entregadas a materias de amor». J osé M. CAso, «La poesía comprometida de Meléndez Valdés», en La literatura española de la Ilustración: Homenaje a Carlos III. Madrid, Universidad Complutense, 1989, págs. 53-72), siguiendo la tendencia de los críticos modernos, no duda en distinguir a la vista de estos testimonios dos estilos, más que épocas, en la poesía de Meléndez, proponiendo a su vez una diferenciación entre poesía filosófica y poesía comprometida según 
llegó a imprimir ${ }^{38}$. Algunas de estas razones parecen sonar en la Epístola dedicatoria a J ovellanos que precede a la primera edición de 1785: al ofrecerle las primicias de su blanda musa, hace, junto al reconocimiento público de su magisterio, una profesión de fe poética menor

\author{
Otros, J ovino, cantarán la gloria \\ de los guerreros... Otros, el vicio \\ hiriendo con su azote \\ [... otros] explicarán las leyes \\ con que en torno del sol la tierra gira, \\ [... ] 0 como \\ del desorden tal vez el orden nace \\ [... ] Mi pacífica musa no ambiciosa \\ se atreve a tanto; el delicado trino \\ de un colorín, el discurrir suave \\ de un arroyuelo entre pintadas flores \\ de la traviesa mariposa el vuelo, \\ y una mirada de Dorila o Filis, \\ un favor, un desdén, su voz incitan.
}

A pesar de la dualidad que establece con la M inerva del magistrado J ovino, no duda en expresar su intima comunión con el maestro por esta misma vía de la sabiduría: "Tú me llevaste de Minerva al templo, / tú me llevaste; y mi pensar, mis luces, / mi entusiasmo, mi lira, todo es tuyo» 39 . Bajo tal protección

tuviera por objeto asuntos generales o problemas concretos, de difícil aceptación. Más atinadas, hablando de estilos, parecen las reflexiones de Juan Bautista A rriaza en el prólogo a la segunda edición de sus Ensayos poéticos (Madrid, 1807), donde refiere los caracteres del filosofismo, la «nueva secta» sucesora del culteranismo y conceptismo, y que como ellas participaba de los mismos elementos de hinchazón y obscuridad: verso suelto, estilo declamatorio, tono sentencioso, lección moral que serían, a su juicio, las notas predominantes del filosofismo. A la vista de estos caracteres es evidente la evolución experimentada por la poesía didascálica, nacida en los años setenta en simple oposición al género amatorio o erótico, hasta erigirse en movimiento poético o filosofismo. La evolución del estilo de Meléndez, dentro de una compleja producción literaria que hermana hasta el fin géneros diversos, se presenta así como una cuestión a matizar en distintas etapas de su vida, muy marcadas hasta 1797 por el ejemplo y guía de Jovellanos. Cf. William E. Colford, J uan Meléndez Valdés. A study in the transition from Neo-Classicism to Romanticism in Spanish Poetry. New York, Hispanic Institute in the United States, 1942; R inaldo FroLDI, Un poeta iluminista: Meléndez Valdés. Milán, I. E. Cisalpino, 1967; J ohn H.R. Polt, Batilo. Sobre la evolución estilística de M eléndez Valdés. Oviedo, Centro de Estudios del Siglo XVIII, 1987.

38 P oesías de D. J uan M eléndez Valdés, Dr. en leyes, y Catedrático de P rima de Letras Humanas de la U niversidad de Salamanca. Tomo I, Madrid, por D. J oaquin Ibarra, 1785. Según Sempere, (Biblioteca, pág. 60), el volumen contendría una docena de poesías, cuya referencia e identificación precisa se contiene en algún caso en la edición de las Obras en verso de Polt y Demerson: odas filosóficas y sagradas (págs. 845 y ss) y elegías morales (págs. 1.003 y ss).

${ }^{39}$ Epístola dedicatoria al Señor Don Gaspar Melchor de J ovellanos, en Poesías de D. J uan Meléndez Valdés, págs. I-VIII; Obras en verso, págs. 763-767. 
presenta al público sus poesías "en un tiempo en que la ignorancia y la envidia se han unido estrechamente para desacreditar y morder cuantos versos salen a luz», invocando el ejemplo de ilustres humanistas que no desdeñaron reunir la poesía con los estudios más austeros ${ }^{40}$.

En los años siguientes desarrolló M eléndez una poesía de carácter más grave, acomodándose al progreso de edad, estado, destino y situación al que al udiera en su Advertencia. Dios, virtud, orden, noble tradición enfrentada a la corrupción de costumbres, artes, forman parte de ese ideario poético grave que, en 1789, coincidiendo con su acceso a la magistratura, parece entrar también en crisis. En la égloga El zagal del Tormes, fechada en ese año, refleja la desolación que le causa el cruel destino (no su deseo) que fiero le arrastra a los lejanos valles del Ebro para ocupar la plaza de alcalde de crimen de la A udiencia de Zaragoza ${ }^{41}$. De creer al poeta, el cansado puesto, tras la ardiente juventud («danzas, amores/cantares, risas, doloridas ansias, / dulces zozobras, veladores celos, I paces, conciertos agradables») y la serena madurez, pone fin al bien natural de la feliz morada a orillas del Tormes así como al moral de los amigos fieles:
¿A qué otros bienes,
otras riquezas y cansados puestos?
¿A qué buscar en términos distantes
la dicha que me guardan estas vegas,
y estas praderas y enramadas sombras?
Téngase allá la pálida codicia
su inútil oro, y la ambición sus honras;
que igual alumbra el sol al alto pino
y al tierno arbusto que a sus plantas nace.

Esta retórica reflexión y su corolario del desprecio mundano, tan común en la poesía ilustrada, tiene su continuación en la silva IV «A las Musas» en las que el poeta, «ya rendido» por el oficio, vuel ve a implorar su favor. La hechicera magia de la loca ambición y la triste edad del alma le ha condenado a mil cuidados:

\footnotetext{
${ }^{40}$ Advertencia [de la edición de 1785], en Obras en verso, págs. 69-70.

${ }^{41}$ P oesías en verso, págs. 589-592. Un detalle de sus ocupaciones gubernativas y judiciales a la luz de las Ordenanzas de la A udiencia pero sin tener en cuenta el estilo o práctica penal recogida en 1733 por Luyando [Manuel Fernández de Ayala Aulestia, Práctica y formulario de la Real Chancillería de Valladolid, reimpresa con método más claro, con una breve clara instrucción del modo de proceder en causas criminales, por don J osé de Luyando, agente fiscal civil y criminal de la Real Audiencia de Zaragoza (Zaragoza, 1733)], en DemerSON, J uan M eléndez Valdés, págs. 259-279; sobre su actividad paralela en la Sociedad Económica, vid. también A ntonio A storgano A bajo, «J uan M eléndez Val dés en la R eal Sociedad Económica A ragonesa», en Revista de Estudios Extremeños, LI (1995), págs. 103-175.
} 
Crudo decreto de malignos hados

dióme de Temis la inflexible vara;

y que mi blando pecho

los yerros castigara

del delincuente, pero hermano mío

Astrea me ordenó, mi alegre frente

de torvo ceño oscureció inclemente

y de lúgubres ropas me vistiera.

Yo mudo, mas deshecho

en Ilanto triste su decreto impío

obedecí temblando

y subí al solio y de la acerba diosa

las leyes pronuncié con voz medrosa...

Pero jah Musas! que el cielo

por siempre me cerró la florecida

senda del bien; y a la cadena dura

de insoportable obligación atando

mi congojada vida,

alguna vez Ilorando

puedo engañar mi desventura

con vuestra voz y mágicos encantos.

Musas, amables Musas, de mis penas

benignas os doled: vuestra armonía

temple el son de las bárbaras cadenas

que arrastro miserable noche y día.

Este lamento del magistrado, que opone la armoniosa poesía a la severa justicia, es posible que se atenuara en su etapa ulterior de oidor en la Audiencia y Chancillería de Valladolid (1791-1798) cuando, más asentado en la judicatura y con profesión de jurisdicción civil, vivió unos años dorados de fecunda creatividad.

A esta etapa corresponde la redacción del poema didáctico «El Magistrado» que pretendía responder a las críticas de cierto colega por su dedicación, en palabras de Llorente, "a la poesía ligera en detrimento del deber profesional», acusándole al tiempo de ignorar el sentido del cargo. La pérdida del poema, del que sólo queda la traducción del prólogo hecha por Desdevises du Dezert relativa al traje del magistrado42, impide conocer el alcance de la respuesta, pero

${ }^{42}$ G. Demerson, J uan Mélendez Valdés, págs. 175-177. 
en todo caso debió aumentar la prevención del magistrado poeta a tenor de la larga Advertencia a la nueva edición de sus Poesías en $1797^{43}$.

Repasando el origen y los logros de la primera edición, señaladamente el haber «ayudado acaso a formar el gusto de la juventud y hacerle amar la sencillez y la verdad», dedicaba el resto de la Advertencia a justificar la impresión de la segunda a partir de la nueva experiencia de combinar la poesía, en especial la de versos llenos de las verdades más importantes de la moral y la filosofía, con la ilustre y austera carrera de la toga. Por más que la censura y la malignidad le hicieran cargo de una distracción inocente, jamás ésta le había robado ni un instante a las graves tareas de mi profesión, ni a la severidad de la justicia. La calumnia, así, no había podido impedir la nueva edición de las poesías, corregida y aumentada en casi una tercera parte respecto a la primera impresión, sino que, bajo el manto protector del exemplum de antiguos magistrados, humanistas, filósofos, papas y reyes sabios, un magistrado se atrevía a aparecer en público declarándose autor por igual de los poemas agradables, de los serios, de los amorosos, de los filosóficos y morales. La unidad del «árbol de la sabiduría» se oponía a aquellos que miraban con malos ojos a los que divagaban un tanto de su profesión y estudios mientras que en los clásicos se encontraba con cierta frecuencia al gran hombre que aspiraba a serlo todo: poeta, orador, filósofo, político, en definitiva, «literatos y hombres públicos». Meléndez, fijados los términos de su adscripción humanista, pasaba a describir el método y las fuentes de inspiración poética distinguiendo en sus poesías un doble género fundamental: el de las poesías agradables, de fuerte impronta clásica, y el de las poesías fil osóficas y morales de las que decía haber cuidado especialmente el estilo («explicarme con nobleza») y el lenguaje («digno de los grandes asuntos que he tratado»), pese a reconocer una insuficiencia propia aliada con la «gran dificultad» de aplicar la lengua castellana a la filosofía. Considerando por ello a sus poemas filosóficos pruebas o primeras tentativas, no dudaba en Ilamarse a sí mismo un aficionado capaz de señalar la ruta a seguir por otros jóvenes poetas, como L eandro M oratín, Cienfuegos - Quintana, llamados a ser «la gloria de nuestro Parnaso». Pero si la carrera negociosa de la magistratura, dando en parte la razón a sus críticos, le impedía dedicarse a los estudios que un tiempo fueran sus delicias («cuando la obligación habla, todo debe callar»), no debía sin embargo silenciar sus exhortaciones para que otros siguieran la difícil senda. Él mismo, al defender las Buenas L etras («ellas forman el gusto, suavizan las costumbres, hacen deli-

${ }^{43}$ P oesías del Dr. J uan M eléndez Valdés, del Consejo de S. M., Oidor de la Chancillería de Valladolid. Valladolid, Por la viuda e hijos de Santander, 1797. 
ciosa la vida, más agradable la amistad, perfeccionan la sociedad, estrechan sus vínculos entre los hombres, y los alivian y entretienen en sus ocupaciones y cuidados»), volvía a recordar in fine que nadie puede vivir sin alguna distracción, con lo que el duelo planteado entre poesía y magistratura quedaba en definitiva en tablas.

A ños atrás, otro magistrado atípico, Forner, conocido en los ámbitos judiciales de su cargo fiscal de la A udiencia de Sevilla primero y después del Consejo de Castilla con el sobrenombre despectivo de el poeta, había reflexionado con severidad sobre «este superfluo empleo de sus horas» por parte de los magistrados:

A nadie menos que a un magistrado puede ni debe disimulársele este superfluo empleo de sus horas. La viuda, el huérfano el pupilo, el pálido y miserable encarcelado, el inocente oprimido de la prepotencia ambiciosa, el ciudadano honesto reducido a la mendiguez por las cavilaciones de la avaricia, en suma, los hombres, los pueblos y las provincias tienen librada su seguridad y felicidad en nuestra vigilancia y en los ahorros de nuestro ocio ${ }^{44}$.

Forner, que en su carrera por el poder ha cometido excesos poéticos superiores a los de su condiscípulo Meléndez ${ }^{45}$, siempre había sentido cierta ani-

${ }^{44}$ Juan Pablo Forner, Discurso sobre la tortura. Edición de Santiago Mollfulleda, Barcelona, 1990, pág. 138; cf. Lucien Domergue, «A propos de la torture et de la peine de mort: un noyau sévillan de résistance à la reforme du droit penal (1774-1792)», en Cahiers de Caravelle, 31 (1978), págs. 75-90; Gonzalo Martínez Díez, «La tortura judicial en la legislación histórica española», en Anuario de Historia del Derecho español, 32 (1962), págs. 223-300; F rancisco Tomás y VAlIENTE, La tortura en España. Estudios históricos. Barcelona, A riel, 1973.

${ }^{45}$ J ovellanos, en su terrible epitafio a Forner (fallecido el 16 de marzo de 1797 a los 41 años de edad tan desamado en el foro como en el Parnaso), achacaba el ascenso del valenciano a su rendida adulación a Godoy en forma de poemas que llegaron a cantar al caballo Mon plaisir del favorito. La sátira «atroz, amarga y llena de injurias y personalidades» del Forner de la primera época, creó una genial oposición entre ambos similar a la que le comentara fray Diego González entre Meléndez y Forner en los inicios de su correspondencia. En mayo de 1777 fray Diego le había hecho llegar una epístola de Juan Pablo Forner, advertida de la opinión contraria de Meléndez («parécenle duras y desabridas a su dulce ánimo», Jovellanos, Correspondencia, I, pág. 57. En medio de las muchas bellezas que tanto J ovino como Delio hallan en las composiciones de F orner, J ovellanos las encuentra nimiamente confusas (ibidem, pág. 61). Pocos años después, en 9 de noviembre de 1784, J ovellanos a la vista del rumbo que está tomando la poesía en manos de Forner, que en 1782 publicara El asno erudito contra Iriarte, aconseja a Cándido María Trigueros que trabaje en las obras proyectadas (unas memorias de agricultura, artes y comercio de Andalucía al estilo de las de Cataluña de Capmany) y se guarde de hacer poesías (déjese de ha cer poesías que son la piedra de choque donde tropiezan nuestros aprendices de literatos) (ibidem, pág. 292). Cf. J ovellanos, Obras completas, tomo VII, Diario, 2.‥ E dición crítica, prólogo y notas de M. T. Caso Machicado y J. González Santos, Oviedo, Centro de Estudios del Siglo XVIII-A yuntamiento de Gijón, 1999, (Diario de 23 de mayo de 1797), pág. 704; cf. Diario de 23 de septiembre de 1795, donde ya adelantaba el mal concepto que tenía de Forner, envidioso y plagiario (ibidem, pág. 445), que se suma a la vieja enemiga declarada con motivo de su Oración apologética por la España y 
madversión por los magistrados: «L os reverendos togados / negra y funesta familia / que parece que en entierro / Ilevan siempre la justicia»), a los que llama, tal vez para responder al desprecio de quienes le consideraban mal jurista, «rancios», «iletrados» 0 «inciviles» ${ }^{46}$. Este desencuentro llegaría a su extremo tras su nombramiento como fiscal del Consejo de Castilla en julio de 1796. En carta a Godoy, le hace partícipe de su propósito de hacer trabajar a un Consejo que está a la expectativa y le teme medianamente ${ }^{47}$. La dualidad poeta-jurisperitos de la que hace gala, amén de la injusta caracterización de poeta arriero frente a magistrados modorros, muestra hasta qué punto el desencuentro con la al ta magistratura 0 , incluso, el desdén recíproco presidió desde un principio su labor fiscal en el Consej ${ }^{48}$. En cualquier caso no hubo tiempo ni posibilidad al guna de armonizar la dura poesía de Forner con su propia imagen satirizada de la magistratura.

su mérito literario. Madrid, Imprenta R eal, 1786. Vid. Jovellanos, Romance contra F orner, en Obras completas. Obras literarias, págs. 245-255.

46 «R omance dedicado a Godoy, Príncipe de la Paz» en Poetas líricos del siglo xVIII (BAE, 63), pág. 327. En la «E pístola a Llaguno» (ibidem, pág. 316), en la Noticia del licenciado Pablo I gnocausto y razón de la obra, todo en una pieza, especie de prólogo que añadiera a la primitiva redacción de las Exequias de la lengua castellana (1788?) (ibidem), Forner critica a los magistrados siendo habitual en él calificarlos de este modo tal vez para responder a sus ataques previos al «Poeta». En la Noticia del licenciado Pablo Ignocausto, especie de autobiografía jurídica, Forner se declara licenciado ambiguo amén de cruel socarrón. Su método de estudio de la jurisprudencia, siguiendo los pasos trillados, lo cifra en saber leyes con ayuda de la historia, las letras humanas y la buena filosofía. Leyes interpretadas a la luz de la cultura y no de los intérpretes 0 comentaristas (pragmáticos, moriscos de la jurisprudencia, ranícol as, letrados de mazacote, rábulas), por los que siente un vivo desprecio que ejemplifica con el inmortal Bartulo, cuyas páginas le producen náusea. Con gran optimismo, declara del licenciado Ignocausto, su personificación, que «trató la jurisprudencia como filósofo, la filosofía como humanista y como político, y los humanistas como filósofo y como letrado». A simismo, achaca al estilo de los jurisconsultos «aquella respetable horridez, aquella robusta suciedad, aquella terquedad greñuda, aquella borra ensortijada que manifiesta desde luego la fortaleza y masculinidad del discurso», que por desgracia no logró evitar en sus propios escritos forenses. A pesar de adornarse con las virtudes de filosofía, elocuencia crítica y humanismo, sus escritos forenses carecen, como recoge en la crítica que se hacía al licenciado Ignocausto, de la «solidez magistral de su profesión». La conocida dispersión de sus tareas («así amasaba una alegación causídica como hacía un soneto o una canción y tanto forjaba una diatriba filosófica como empuñaba la clava crítica y aporreaba a diestro y siniestro a cuantos espantajos literarios se le ponían por delante»), le impidió ser buen fiscal, en el sentido clásico del término acuñado en su época por Campomanes o Moñino, con unos dictámenes que, a diferencia de los de estos grandes juristas, se presentan como modelos de nimia confusión y culta garrulería. A la espera de la edición crítica de las Exequias de la lengua castellana, anunciada por María C. Carbonell, manejamos la edición de Pedro Sainz Rodríguez, Madrid, Espasa Calpe, 1967. Nuevos ejemplos de su dispersión en Pedro Álvarez de Miranda, «Forner, escritor de encargo. Nuevos datos para su biografía», en Forner y su época (1756-1797), Actas del congreso conmemorativo, Mérida, Editora R egional de Extremadura, 1998, págs. 35-55.

47 «Mis venerables compañeros [del Consejo de Castilla] ya están en espectativa y me temen medianamente. No pueden Ilevar en paciencia que un Poeta haya venido a arrearlos. Aún no han visto lo que es el Poeta; allá lo verán luego que yo asiente mi real y desembalije mis libros y papeles. No daré un paso sin consultarlo con V.E. pero, merecida su aprobación, habrán de tener paciencia los Sres. Jurisperitos. EI Rey nos paga para hacer feliz a la Nación en la parte que podamos, y yo no he de consentir magistrados modorros», Lopez, J uan Pablo F orner y la crisis, pág. 656.

${ }^{48}$ Coronas, Ilustración y Derecho. Los fiscales del Consejo de Castilla, págs. 227-229. 
La Advertencia de Meléndez, una pieza notable tanto por sus declaraciones poéticas como por su incoherencia, no despejaba tampoco la cuestión de las relaciones entre poesía y magistratura pese a la larga justificación de su obra personal. Si de un lado aceptaba la práctica incompatibilidad de las mismas por las obligaciones inherentes al cargo laborioso de magistrado, de otro parecía limitar sus efectos solamente a la poesía de carácter filosófico-moral, cuya gran dificultad confiaba que superase la nueva generación poética. El mismo Meléndez, sin embargo, al cabo de siete años de ejercicio de la magistratura penal y civil en sendas Audiencias del reino, podía ostentar la prueba de su genio en este tipo de composiciones: «El fanatismo» ${ }^{49}$ (1794); «AI Excmo. Sr. D. Eugenio de Llaguno y A mírola, en su elevación al Ministerio de Gracia y J usticia»50 (1794); «El filósofo en el campo»51 (1794); «Al Excmo. Sr. Príncipe de la Paz, exhortando a Su Excelencia a que en la paz continúe su protección a las ciencias y a las artes»52 (1795); "Orden del universo y cadena admirable de sus seres» ${ }^{33}$ (1795); «El bien y el mal» ${ }^{44}$ (1794-1797); «A I Príncipe de la Paz, siendo Ministro de Estado, sobre la calumnia»55 (1796-1797); «AI Excmo. Sr. Príncipe de la Paz, con motivo de su carta patriótica a los obispos de España recomendándoles el nuevo Semanario de Agricultura» ${ }^{56}$ (1797)... , y, una vez logrado su ansiado ascenso a la fiscalía de Casa y Corte, su epístola «A I Excmo. Sr. D. Gaspar M elchor de J ovellanos en su feliz el evación al M inisterio de Gracia y J usticia» ${ }^{57}$ (1797), en la que viene a concentrar todas sus esperanzas ilustradas,

\footnotetext{
${ }^{49}$ Obras en verso, págs. 921-925.

50 Ibidem, págs. 767-772.

51 Ibidem, págs. 783-790.

52 Ibidem, pp.761-763.

53 Ibidem, págs. 1044-1055.

54 Ibidem, págs. 984-988.

55 Ibidem, págs. 814-818.

56 Ibidem, págs. 790-796.

57 «AI Excm. Señor Don Gaspar Melchor de J ovellanos, Caballero del Orden de A Icántara, del Supremo Consejo de Castilla, en su feliz elevación al Ministerio Universal de Gracia y Justicia, su amigo J uan Mélendez Valdés» (Impreso suelto, s. I., s. f.) (¿Valladolid, 1797?); Obras en verso, págs. 796-803.

¿Dejaré yo que pródiga la Fama cante tus glorias y que el himno suene de gozo universal, callando en tanto mi tierno amor su júbilo inefable? [... ] ¡Gloria! ¡felicidad! J ovino amado, dulce amigo, mitad del alma mía, al fin te miro do anhelaba..

[... ] Vílo, sí, yo lo vi; pueblos, sabedlo, y acatad la virtud: yo vi a J ovino triste, abatido, desolado, al mando ir muy más lento que a Gijón le viera trocar un día por la corte. Nunca más grande lo admiré; por sus mejillas
} 
compartidas asimismo por otros jóvenes valores que, como Quintana, entonan con este motivo nuevos cantos de reforma y esperanza ${ }^{58}$. J ovellanos, el maestro común de esas generaciones nacidas ya bajo el signo de la reforma, será ensalzado en ellas como héroe civil, como el hombre de mérito que hace brillar la luz de la esperanza en la España alicaída del escándalo y de la corrupción política, en la querida desolada patria que dijera Meléndez ${ }^{59}$.

\author{
de la virtud las lágrimas corriendo \\ [... ] Pueblos, conmigo \\ venid, uníos; y que el himno suene \\ [... ] Tú en tanto afana, lidia, vence, ahuyenta \\ el fatal genio que su trono infausto \\ en la patria asentó; caiga el coloso \\ del error de una vez, alzando al cielo \\ libre el ingenio sus brillantes alas. \\ Un hombre sea el morador del campo; \\ no los alumnos de Minerva lloren \\ entronizada a la ignorancia altiva; \\ ni cabe el rico la inocencia tiemble. \\ Justa la ley al desvalido atienda \\ inalterable, igual, sublime imagen \\ de la divinidad; y afable ría \\ la confianza en los hispanos pechos
}

58 «A I Excmo. Sr Don Gaspar de J ovellanos. En ocasión de habérsele encargado el ministerio de Gracia y J usticia». La oda, que no figuraba en la colección de Poesías de Quintana de 1802, fue dada a conocer en la edición de 1813. La primera versión de 1797 cotejada con la definitiva de 1813, según el texto fijado por A. Derozier, en su Manuel J osé Quintana. Poesías completas, Madrid, Castalia, 1969.

¿No es éste el suelo

que en otro tiempo a compasión movía?

[... ] Veinte siglos de error en él fundaron

el imperio del mal...

[... ] ¡Ay! hubo un tiempo

que el ser padre era un mal: ¿quién sin zozobra

a la indigencia, al desaliento, diera

nuevos esclavos? Pero huyó; al olvido

lanzó J ovino tan amargos días:

mi esperanza, mi paz, las glorias mías

obras son de su amor, son de su anhelo;

dadme pues sólo el bendecir su nombre,

y en dulces himnos levantarle al Cielo.

59 Vid. la serie extraordinaria de «Festejos y regocijos públicos por el ascenso de J ovellanos al Ministerio de Gracia y Justicia», en S. M. Coronas, J ovellanos. J usticia, Estado y Constitución en la E spaña del Anti-guo Régimen. Gijón, Fundación Foro J ovellanos del Principado de A sturias, 2000, págs. 95- 122; 177 355. A esta época de esperanza, aunque sea tan desalentada como la que ha captado Goya del J ovellanos ministro, corresponde lo más granado de los Discursos forenses de Meléndez. Son diez los textos recogidos por el académico Fernández Navarrete en la edición de la Imprenta R eal de 1821, si bien no todos poseen el mismo carácter forense pues al menos uno de ellos es un fragmento de un discurso filosófico moral sobre el problema de la mendicidad. Si en 1791 pudo exponer el ideario de un magistrado ilustrado ante los jueces de su provincia natal en el Discurso de apertura de la Audiencia de Extremadura, ahora, en 1798, tuvo ocasión de exponer su credo fiscal, igualmente ilustrado, en diversos dictámenes y acusaciones. A trás parece quedar el poeta de la etapa salmantina, el dulce Batilo de las églogas anacreónticas, por más que su sensibilidad 
La dificultad del nuevo género sublime provenía en parte de la inmadurez del espíritu poético español: superados el culteranismo y el conceptismo barroco por el nuevo clasicismo, éste se resistía a su vez a abandonar las dulces composiciones líricas en favor del severo estoicismo de la poesía filosófica y moral. Siguiendo el ejemplo clásico y la nueva inspiración filosófica del siglo, el buen gusto, hecho al estilo sencillo de Feijoo, al erudito de Mayans o al moral y político de J ovellanos, apenas si había tenido tiempo para imponerse en los ámbitos literarios, quedando como una aspiración a hacerse realidad por nuevas generaciones poéticas, como la segunda salmantina. A manera de ejemplo de esta rápida evolución poética, que corre paralela a la política, y en el caso de nuestros magistrados a la jurídica, pudiera citarse uno de los temas propuestos por J ovino al dulce Batilo, la guerra de las Comunidades de Castilla - «la furia canta y las facciones/de la guerra civil que el pueblo hispano/alió y opuso al alemán soberbio» - que tuvo que esperar al genio de Quintana para hacerse realidad, (A «) uan de Padilla» (mayo, 1797) en los orígenes del mito de los Comuneros que tanto juego habría de dar en la historia política ulterior ${ }^{60}$. A sí, hubo que esperar en definitiva un salto generacional para que la poesía política y moral se asentara en el panorama literario español. Como signo de la consagración

reaparezca una y otra vez en sus acusaciones fiscales, circunstancia que no le impide pedir la aplicación de las penas más severas contra los perturbadores del orden conyugal o social.

Al concebir el oficio fiscal como «alma de todo tribunal, que le da... movimiento y dirección», orienta su propia labor en la fiscalía de la Alcaldía de Casa y Corte hacia una filosofía de la legislación que le permite criticar la práctica jurisprudencial de su tiempo: «casos en lugar de principios, raciocinios falsos autorizados como dogmas legales, opiniones particulares erigidas malamente en leyes, doctores y pragmáticos en continua contradicción, y el enredo y el litigio burlándose a su sombra de la sencilla buena fe con descarada impunidad». Haciendo de «la razón y la filosofía... nuestros maestros y sabios consejeros», plantea el ideal de unas «pocas leyes, claras, breves, sencillas, que todos, todos, hasta los más rudos aldeanos entiendan», frente a la realidad abusiva de la recopilación de leyes de todas épocas. Finalmente, sin miedo a la novedad («abracemos con sobria libertad las novedades útiles») reclama la reforma penitenciaria, el castigo pronto y análogo a la ofensa, la supresión del tormento, la reparación de los perjuicios sufridos por el inocente condenado por error, la abreviación y simplificación de las pruebas... , medidas que a su primer editor anónimo de 1821 le hacían presentarle no sólo como el restaurador de la poesía española sino también de la magistratura. Título este último excesivo si comparamos la sobria prosa jurídica de unos fiscales como Campomanes o Moñino, model os de elocuencia forense, con la excesivamente literaria y anafórica de Meléndez, capaz sin embargo de captar inmediatamente el interés popular, como ocurriera desde su primera acusación fiscal (contra Santiago de San Juan y María Vicente Mendieta, reos del parricidio alevoso de Francisco del Castillo, marido de esta última, de 28 de marzo de 1798). Discursos forenses de D. J uan M eléndez Valdés. Edición al cuidado de J osé Esteban, Madrid, 1986 (reproduce la realizada en Madrid, I mprenta Real, 1821); cf. Discurso sobre los grandes frutos que debe sacar la provincia de Extremadura de su nueva Real Audiencia, y Plan de útiles trabajos que ésta debe seguir. Para el día solemne de su instalación y apertura, 27 de abril de 1791. Edición, introducción y notas de Miguel A. Lama, A samblea de Extremadura, 1991; Georges Demerson, «M eléndez Valdés, Extremadura y la A udiencia de Extremadura» en Cuadernos de Investigación Histórica, 9 (1986), págs. 5-16.

60 La famosa oda no pudo figurar en la colección de Poesías de Quintana de 1802, pero sí apareció en la edición de sus Poesías patrióticas (Madrid. Imprenta Real, 1808). Albert Dérozier, Manuel J osé Quintana y el nacimiento del liberalismo en España. Trad. de M. Moya, Madrid, Turner, 1978, págs. 31-34; 186. 
del género llamado a reconstruir la conciencia política patria adormecida por el absol utismo de A ustrias y Borbones, se al zaría años después el P elayo de Quintana, con su canto a la libertad e independencia nacional, «iLibres nacimos! ¡Libres moriremos!», capaz de enardecer a los espectadores tanto del final del A ntiguo R égimen como del nuevo Constitucional ${ }^{61 .}$

Entre ambas generaciones poéticas se alza la revolución F rancesa, superior a cuantas la han precedido en la inmediata percepción de sus contemporáneos ${ }^{62}$. Su sistema de igualdad, con la destrucción de dos de los tres órdenes corporativos del Estado, la nobleza y clero; su mensaje vibrante de libertad consignada en la Declaración Universal de Derechos del Hombre y del Ciudadano y en la rápida serie de Constituciones de la década final del siglo; su fraternidad universal, han hecho palidecer el tímido reformismo dieciochesco al tiempo que alumbra una nueva era política que deja atrás la literaria en expresión del padre Estala. A pesar de la Inquisición y de la censura oficial, la política es el alma de la nueva generación poética. Lo mismo da que sus adalides y maestros estén en España encerrados en prisión, como J ovellanos, o en destierro, como M eléndez. Su ejemplo y recuerdo no se ol vida. E n el silencio amedrentado que siguió a su inicua persecución, hubo de sonar como un clarín la voz valiente de Nicasio Á lvarez Cienfuegos, el antiguo discípulo de M eléndez en Salamanca, celebrando a los maestros caídos en desgracia en su discurso de recepción en la A cademia Española: «los hombres de bien de todos los siglos y naciones os aplauden y os aman» ${ }^{63}$. EI mensaje de probidad moral, superpuesto a la lección poética, había calado hondo en la conciencia crítica de algunos literatos que en esta coyuntura se vieron abocados a decidir entre libertad y autocracia antes de enfrentarse a la gran prueba histórica de la guerra de la Independencia. A lgunos, como Forner 0 , más tarde, M eléndez siguieron el camino trillado del poder, sin olvidar su compromiso reformista; otros, como J ovellanos o Quintana, supieron ser fieles a las raíces patrióticas y libertarias de la nueva filosofía. En ambos casos, la literatura y el derecho, o en escala menor la poesía y la justicia, como si se tratara de una de las hermosas alegorías de la época, fueron juntas.

61 P elayo, tragedia en cinco actos por Don Manuel J osef Quintana, representada en el teatro de los Caños del Peral el día 19 de enero de 1805. Madrid, en la oficina de García y Compañía, año de 1805, 1f.VIII-104 págs. Vid. el análisis de esta y otras obras del mismo género en A. DÉrozier, Manuel J osé Quintana y el nacimiento del liberalismo, págs. 83 y ss.

62 Pedro Rodríguez Campomanes, «R eflexiones sobre la política exterior» (1792) en Inéditos políticos. E dición y estudio preliminar de Santos M. Coronas, Oviedo, J unta General del Principado de A sturias (Colección Clásicos A sturianos del Pensamiento Político, 7), 1996, pág. 163.

63 Discurso de 20 de octubre de 1799. Memorias de la Real Academia Española tomo I, Madrid, 1799, págs. 352-357. 
El joven Manuel José Quintana (Madrid, 1772-1857), que se ha formado en las aulas salmantinas bajo el directo influjo de Meléndez, representa con sus odas tempranas («A Don Juan de Padilla» (mayo, 1797), «A D. Gaspar de Jovellanos, cuando se le encargó el Ministerio de Gracia y Justicia en 1797», «A la invención de la imprenta» (julio de 1800), «El Panteón del Escorial» (abril, 1805), «A la expedición española para propagar la vacuna en A mérica» (diciembre, 1806), y sus tragedias (EI duque de Viseo (1801) o Pelayo (1805), esa nueva "escuela poética» social y patriótica antes que lírica, capaz de enarbolar, a tono con la revolución en ciernes, la bandera de la libertad ${ }^{64}$. La exaltación patria de la libertad, la lucha contra la Inquisición, símbolo del fanatismo religioso y político, la moderación del poder, haciendo que el cetro no fuera más una insignia vil de opresión, la filantropía o el panfilismo que destacara Gómez de Hermosilla, la glorificación de los personajes útiles... , representan algunos rasgos temáticos de esa segunda generación poética salmantina de los Cienfuegos, Gallego, Quintana, Somoza, Sánchez Barbero o A rriaza que saben expresar este haz de sentimientos comunes con un nuevo lenguaje literario más apasionado y político. Por lo general, son dignos continuadores del precepto jovellanista de consignar en el afán poético, materias/ dignas de una memoria perdurable, las mismas que ha recordado Cienfuegos en el prólogo de sus Poesías dedicado A mis amigos (1798): tolerancia, trabajo, verdad, generosidad ${ }^{65} . .$.

Quintana, abogado y procurador fiscal de la Junta de Comercio y M oneda, aunque se considera desde 1802 sujeto a ocupaciones muy ajenas de la amenidad de las Musas ${ }^{66}$, es un escritor fecundo que en 1808, bajo el signo de la libertad, colecciona sus Poesías patrióticas ${ }^{67}$. Es ahora, al calor de esas poesías

\footnotetext{
${ }^{64}$ Salamanca, en la correcta interpretación de Dérozier, representa más bien un lazo de unión simbólica que una auténtica escuela poética. Más allá del espíritu que encarna fray Luis de León se esconde toda la complejidad de influencias sintetizadas en la fórmula anglo-galo-filosófico-sentimental, que agudamente percibieran Tineo y Gómez de Hermosilla. Vid. J. Gómez Hermosilla, J uicio crítico de los principales poetas españoles de la última era. Valencia, Imprenta de Vicente Salvá, 1840; una rápida caracterización del grupo en Marcelino Menéndez y Pelayo, Historia de los heterodoxos españoles. Madrid, Biblioteca de Autores Cristianos, 1978, II, págs. 550-560; cf. César ReAL DE LA RIVA, «La escuela poética salmantina del siglo XVIII», en Boletín de la Biblioteca Menéndez y Pelayo, XXIV, 1948, págs. 321-364. Para otras cuestiones conexas, remito a mi estudio sobre J ovellanos y la Ilustración jurídica en Salamanca, en EI derecho y los juristas en Salamanca (siglos xvı a xx). Universidad de Salamanca (en prensa).

65 Nicasio Á lvarez de Cienfuegos, Obras poéticas. Madrid, Imprenta Real, 1816, en la que figura la carta dedicatoria A mis amigos, de la edición de 1798.

${ }^{66}$ Dérozier, Manuel J osé Quintana, pág. 181.

${ }^{67}$ Poesías patrióticas de D. Manuel J osef Quintana. Madrid, en la Imprenta Real, 1808. A unque algunas poesías ya habían sido publicadas en la colección de 1802, como la oda «A la invención de la imprenta», ahora se vuelven a editar con todas las variantes que las cadenas que entonces aprisionaban la verdad entre nosotros no le habían permitido (prólogo).
} 
que incluyen pasajes tan significativos como el de «iAy del alcázar que al error fundaron/ la estúpida ignorancia y tiranía», que comienza a hablarse del «partido de Quintana» ${ }^{68}$. Un partido literario con vocación política que exalta la libertad histórica a la española en la línea de su maestro J ovellanos. A sí, en su Defensa de las poesías ante el tribunal de la Inquisición ${ }^{69}$ no duda en basar ese concepto de libertad en las antiguas máximas de los publicistas, en las crónicas e historias, en las mismas compilaciones legales que, en conjunto, permitían hablar de una «monarquía templada y mitigada por las leyes»70. Quintana, «El Señor Filósofo y Poeta» en la expresión denigratoria de sus detractores, sabe combinar la cultura del momento de fuerte inspiración francesa ${ }^{71}$ con el genio nacional. Pasada la época de la exageración y de la efervescencia juvenil, cuando al grito de libertad entonado en Francia la conciencia se abandona al sentimiento delicioso que inspiraba la bandera del bien desplegada en el aire haciendo huir delante desí los vicios, los abusos, los errores de la humanidad degradada72, Quintana se vuelve patriota. La historia patria le enseña modelos de libertad: Guzmán el Bueno, Padilla, el héroe de las Comunidades castellanas, Lanuza, el de los sucesos de Aragón, Pablo Clarís, el de la Cataluña antiborbónica, muestran

68 Manuel Freire de Castrillón, Delación a la Patria de las Poesías Patrióticas de D. Manuel Quintana, Madrid, en la Imprenta Real, 1808; cf. A lbert DÉROZIER, «Polemique sur un pasaje de Quintana (un anti-iAy del alcázar en 1814)», en Les langues neo-latines, 168 (marzo-abril 1964), págs. 31-45.

${ }^{69}$ (Calificación y censuras dadas a mis poesías impresas en 1813, a fin de que conteste a ellas) (Ciudadela de Pamplona 9 de agosto de 1818), en Obras inéditas del Excmo. Señor D. Manuel J osé Quintana, precedidas de una biografía del autor por su sobrino D. M. J . Quintana. Madrid, Medina y Navas, 1872, págs. 77-106.

70 «Esta doctrina de la moderación y de templanza en la autoridad soberana para que el gobierno no degenere en opresión y en tiranía, no es tan nueva, Sr. IImo., ni tan desconocida entre nosotros, que haya que ir a beberla en la filosofía y en la revolución Francesa. Ella se deduce clara y distintamente de las máximas de nuestros publicistas, de los sucesos contados por nuestros historiadores, y de los mismos códigos de nuestras leyes, llenos de estos recuerdos y documentos». «Memoria sobre el proceso y prisión», en Obras inéditas, cit. [n. 69] . Vid. sobre esta cuestión, Santos M. Coronas González, «Las leyes fundamentales del A ntiguo R égimen (Notas sobre la Constitución histórica española)», en Anuario de Historia del Derecho español, LXV (1995), págs. 127-218 (reproducido con ilustraciones en sus E studios de Historia del Derecho Público, Valencia, 1998, págs. 178-323); del mismo autor, Libertades y derechos en la España del Antiguo Régimen, Valladolid, Instituto Histórico Simancas, 2003.

71 «No había pues otro rumbo que seguir, dado que no era fácil, ni acaso posible, tener uno propio, que el que señalaba el ingenio francés. Todo concurría a este efecto inevitable: nuestra corte, en algún modo francesa, el gobierno siguiendo las máximas y el tenor observados en aquella nación; los conocimientos científicos, las artes útiles, los grandes establecimientos de civilización, los institutos literarios, todo se traía, todo se imitaba de allí: de allí el gusto en las modas, de allí el lujo en las casas, de allí el refinamiento en los banquetes; comíamos, vestíamos, bailábamos, pensábamos a la francesa; ¿y extrañamos que las musas tomasen también algo de este aire y de este idioma?» M. J. QuintanA, Introducción a la poesía castellana del siglo XVIII, en Poesías selectas castellanas desde el tiempo de J uan de M ena hasta nuestros días, en Obras completas de Manuel J osé Quintana (BAE, XIX), Madrid, M. Rivadeneyra, 1867 (A tlas, 1946), pág. 146.

72 Dérozier, Manuel J osé Quintana, pág. 365; sobre la evolución de su pensamiento, cf. Memoria sobre el proceso y prisión $B A E, X I X$, págs. 168-169. 
el camino del antiguo patriotismo que renace con fuerza tras la revolución de 1808, cuando los déspotas antiguos / consternados y pálidos se esconden ${ }^{73}$. Un patriotismo que ayuda a difundir con sus Vidas de españoles célebres $(1807)^{74}$ y con el Semanario patriótico (1808) donde acuñará el concepto clásico de patria como libertad.

Este concepto, de la mano de la epopeya medieval que pervive en el romancero, se hará romántico conforme a la sinonimia establecida por el mismo Quintana. A hora, en el tiempo heroico de la guerra de la Independencia, tiene ocasión de revivir. En la disyuntiva que se ofrece a los ilustrados en 1808 de elegir entre la patria y la luz de la monarquía bonapartista, Quintana no duda en elegir la primera. Por instinto, como el bajo pueblo; pero también por compromiso personal con la historia que ha cantado en sus héroes de libertad e independencia, elige la causa de la resistencia, asumiendo frente a muchos de sus antiguos maestros y amigos afrancesados (Meléndez Valdés ${ }^{75}$, Moratín, Lista... ) el

${ }^{73}$ «A España, después de la revolución de marzo» (abril, 1808), en Poesías de D. Manuel J osef Quintana. Tercera edición aumentada y corregida. Tomo I, Madrid, Imprenta Nacional, 1821, págs. 215-221.

Los déspotas antiguos

consternados y pálidos se esconden:

resuena el eco de la venganza en torno,

y del Tajo las márgenes responden

«¡Venganza!» ¿Dónde están, sagrado río,

los colosos de oprobio y de vergüenza

que nuestro bien en su insolencia ahogaban?

Su gloria fue, nuestro esplendor comienza;

y tú orgulloso y fiero,

viendo que aún hay Castilla y castellanos,

precipitas al mar tus rubias ondas

diciendo: «Ya acabaron los tiranos».

[... ] Despertad, raza de héroes, el momento

llegó ya de arrojarse a la victoria;

[... ] No ha sido en el gran día

el altar de la patria alzado en vano

por vuestra mano fuerte:

juradlo, ella os lo manda: "iA ntes la muerte,

que consentir jamás ningún tirano!»

[... ] ¡Salud, oh padres de la patria mía,

yo les diré, salud!

74 Vid. especialmente su prólogo en Obras completas (BAE, XIX), pág. 201.

75 El triste papel de Meléndez en la España de la revolución se inserta en un fácil oportunismo que le Ilevó primero a ser juguete de la J unta Suprema de Gobierno, nombrada por Fernando VII antes de emprender su marcha a Bayona, y después del gobierno constituido de José Napoleón I. Al servicio de la primera Ilevó a cabo el desatentado viaje o comisión de paz a la A sturias que había declarado solemnemente la guerra a Napoleón el 25 de mayo de 1808, un «encargo pacífico de mera exhortación», en sus palabras, que estuvo a punto de costarle la vida. Al servicio del gobierno francés, el autor de sendas Alarmas contra los franceses, permaneció en Madrid, aceptó el cargo de fiscal de las J untas de Negocios Contenciosos encargadas de resolver los negocios de esta índole en curso ante el Consejo de Castilla (decreto de 6 de febrero de 1809; P ron- 
papel de poeta nacional. Su España libre (Madrid, Imprenta R eal, 1808), sus Poesías patrióticas y su Semanario Patriótico (que apareció en Madrid el 1 de septiembre de 1808 iniciando el periodismo político en España) ayudan a despertar la conciencia patria de libertad, como lo hiciera el Ensayo histórico crítico ${ }^{76}$ de Martínez Marina y la toma de partido por la causa de mi país de J ovellanos, anunciada a sus antiguos amigos Mazarredo y Cabarrús ${ }^{77}$. Para Quintana, parecía quedar atrás el tiempo literario de la oda, del soneto, de la elegía y de la tragedia; al frente se avistaba ya el tiempo político de la proclama, del manifiesto y del artículo en la prensa militante; el tiempo nuevo de la libertad en la era de la política.

\footnotetext{
tuario de las leyes y decretos del rey nuestro señor Don J osé Napoleón I desde el año de 1808, tomo I, Madrid, en la Imprenta Real, 1810, págs. 81-83) y el 2 de noviembre de 1809 fue elevado a consejero de Estado, cargo en el que permaneció hasta 1813, trabajando activamente en diversas comisiones como la del Código Civil (en la adaptación del Code Civil a E spaña) o de Instrucción Pública cuya presidencia ostentó. Socio tardío de la E conómica Matritense (1811-1813) y encargado por ella de hacer el elogio fúnebre del socio Gaspar Melchor de Jovellanos para su publicación, el antiguo poeta llorón, el autor de sendas odas a José I tan sensibles como las de sus primeros cantos a Filis (que manifiesta especialmente en su oda «Al Rey Nuestro Señor» (1810) («mis ojos se arrasaron en agua deliciosa; latióme el pecho en inquietud sabrosa / y mi amor y mi fe más se inflamaron)», y que en la oda «España a su rey en su feliz vuelta de Francia» (1811) dijera en rendida adulación «... y de tu estirpe clara mil reyes tras ti vea»), no encontró tiempo para llorar la muerte de su amigo del alma, pero sí para corregir la exposición de presentación al rey de los tomos de las Memorias de la Matritense. De este modo indigno, el dulce Batilo de la ridícula mascarada de la A rcadia salmantina puso triste colofón a su antigua relación con el gran J ovino.

${ }^{76}$ Ensayo histórico crítico sobre la antigua legislación y principales cuerpos legales de los reinos de León y Castilla. Madrid, 1808. La obra, considerada por Jovellanos un «rico tesoro de erudición escogida y recóndita», fue escrita con finalidad de lograr el restablecimiento de la antigua constitución de Castilla: «Con este fin publiqué en el año de 1808 el Ensayo histórico-crítico sobre la antigua legislación de los reinos de León y Castilla, fruto de prolijas investigaciones sobre nuestra jurisprudencia nacional y de la más seria y combinada meditación de hechos históricos, memorias y documentos preciosos poco conocidos, olvidados o despreciados por nuestros escritores, sin embargo de que en ellos se encuentran las semilla de la libertad española y los fundamentos de los derechos del ciudadano y del hombre... También se han indicado en ella los medios adoptados por nuestros padres para conservar su independencia y las principales leyes fundamentales de la monarquía española y de la antigua constitución de Castilla para que el público las conociese y diese al gún paso para mejorar de situación.» F. Martínez MARINA, Teoría de las Cortes o grandes J untas Nacionales de los reinos de León y Castilla. Madrid, 1813, prólogo, n.․ำ 102.

${ }_{77}$ En la carta a J osé de Mazarredo (J adraque, 21 de junio de 1808; en G.M. de Jovellanos, Obras completas, tomo IV, Correspondencia 3.․ Edición de J. M. Caso González, Oviedo, Centro de Estudios del Siglo XVIII-Ayuntamiento de Gijón, 1988, págs. 554-555), J ovellanos, al rechazar la comisión pacificadora a A sturias que le ha propuesto el gobierno interino, alude al juicio de la nación que se ha declarado generalmente contra la Francia invasora, haciendo suya la causa de mi país que puede ser temeraria pero es a lo menos honrada. Una causa que sin dejar de ser dinástica en su sentido histórico (¿Valdrá tanto un hermano de Napoleón como el descendiente de Recaredo, de Pelayo y de F ernando el 3? ?) es, sobre todo, política: España no lidia por los B orbones ni por Fernando; lidia por sus propios derechos, derechos originales, sagrados, imprescriptibles, superiores y independientes de toda familia o dinastía. España lidia por su religión, por su Constitución, por sus leyes, sus costumbres, sus usos, en una palabra por su libertad (Madrid, Cátedra, 1988, 11. a ed.), pág. 241.
} 